\title{
Densitas Energi Konsumsi dan Densitas Asupan Protein Berhubungan dengan Status Gizi Anak Usia Sekolah
}

\author{
Debby Endayani Safitri*, Zenia Elsa Fitri, Widya Asih Lestari \\ Prodi Ilmu Gizi, Fakultas Ilmu-ilmu Kesehatan, Universitas Muhammadiyah Prof. DR. Hamka, Indonesia \\ *Corresponding author: debby_endayani@uhamka.ac.id
}

\begin{abstract}
Background: One of nutrition problem in children aged 10-12 years is overweight. Changes in food consumption patterns such as high energy density foods as well as low consumption of vegetables and is thought to be a trigger factor for the high prevalence of over nutrition in children. Purpose: The purpose is to determine the relationship of dietary energy density, protein intake density, and fiber intake density to nutritional status. Methods: This research used a quantitative method with a cross-sectional design and a sample of 46 children aged 1012. Data were collected by interview method, anthropometric measurement and observation. The statistical analysis used was Spearman's correlation. Result: The results showed that 4.3\% of the children were underweight, $69.6 \%$ were normal and $26.1 \%$ were overweight. Most children have sufficient energy and protein intake densities but low in fiber intake. Conclusion: There is a significant relationship between energy consumption density and protein intake density with children nutritional status.
\end{abstract}

Keywords: energy density; protein density; nutritional status

\begin{abstract}
ABSTRAK
Latar belakang: Masalah gizi pada anak usia 10-12 tahun satu diantaranya adalah gizi lebih. Perubahan pola konsumsi pangan seperti tingginya konsumsi makanan berdensitas energi tinggi dan rendahnya konsumsi sayur buah diduga menjadi faktor pemicu tingginya prevalensi gizi lebih pada anak. Tujuan: Tujuan dari penelitian ini adalah mengetahui hubungan densitas energi konsumsi dan densitas asupan protein dan serat dengan status gizi. Metode: Metode yang digunakan dalam penelitian ini adalah pendekatan kuantitatif dengan desain crosssectional, sampel berjumlah 46 anak berusia 10-12 tahun. Data dikumpulkan dengan metode wawancara, pengukuran antropometri dan observasi. Analisis statistik yang digunakan adalah korelasi Spearman. Hasil: Hasil penelitian menunjukkan bahwa 4,3\% anak dengan status gizi kurus, 69,6\% normal dan 26,1\% gemuk. Sebagian besar anak memiliki densitas asupan energi dan protein yang cukup namun densitas asupan serat sebagian besar anak dalam kategori rendah. Simpulan: Terdapat hubungan yang signifikan antara densitas energi konsumsi, densitas asupan protein dengan status gizi anak.
\end{abstract}

Kata kunci: densitas energi, densitas protein, status gizi 


\section{PENDAHULUAN}

Salah satu faktor yang menentukan kemajuan suatu bangsa ialah Sumber Daya Manusia (SDM). Kualitas SDM yang tinggi dipengaruhi oleh banyak hal dimana gizi yang baik menjadi salah satunya (1). Masalah gizi lebih pada anak menjadi salah satu tantangan yang perlu mendapatkan perhatian khusus di abad ke-21 dikarenakan peningkatan prevalensi terus terjadi dari tahun ke tahun di berbagai belahan dunia (2).

Secara keseluruhan, prevalensi gizi lebih pada anak 5-12 tahun di Provinsi Banten yaitu sebesar 20,1\% yang terdiri dari $10,1 \%$ anak gemuk dan 10,0\% lainnya obesitas. Apabila dibandingkan dengan prevalensi nasional yaitu sebesar 20\% maka provinsi Banten sudah berada di atas angka nasional (3). Gizi lebih pada anak berdampak signifikan terhadap proses tumbuh kembang, khususnya dalam aspek psikologi emosional, meningkatkan risiko terkena penyakit degeneratif dan atau metabolik serta berisiko tinggi menjadi obesitas saat dewasa (4).

Perilaku selektif dalam memilih makanan harus diterapkan mulai saat ini dikarenakan perkembangan zaman semakin memudahkan manusia untuk mengakses makanan padat energi namun rendah mikronutrien atau disebut juga dengan energy-dense, nutrient-poor foods (EDNP) yang berhubungan dengan kejadian gizi lebih (5).

Secara nasional, proporsi kebiasaan anak usia 10-14 tahun dalam konsumsi makanan berisiko cukup tinggi.

\section{METODE}

Penelitian ini menggunakan desain kuantitatif dengan pendekatan cross sectional. Tempat penelitian di lingkungan Rukun Warga (RW) 08 Larangan Selatan,
Berdasarkan data Riset Kesehatan Dasar (Riskesdas) pada tahun 2018 didapatkan proporsi anak usia 10-14 tahun dalam hal konsumsi makanan berisiko yaitu sebesar $44,2 \%$ anak mengonsumsi makanan berlemak dan makanan serta minuman berpemanis dengan proporsi sebesar 50,4\% dan $61,86 \%$. Kemudian, proporsi perilaku konsumsi kurang sayur dan buah mencapai 95,4\%, tidak tampak perubahan bahkan terdapat peningkatan dibandingkan pada tahun 2013 yaitu 93,6\%. Secara keseluruhan dapat dilihat jika anak di Indonesia cenderung mengonsumsi makanan berdensitas energi tinggi (3).

Selain itu, terdapat juga faktor lain yang memengaruhi status gizi pada anak yaitu aktivitas menetap atau disebut dengan perilaku sedentari. Perilaku sedentari menjadi isu penting yang sedang dibahas di sebagian negara karena memberikan efek negatif bagi kesehatan (6). Perilaku sedentari mengakibatkan rendahnya pengeluaran energi sehingga tidak menutup kemungkinan akan terjadi ketidakseimbangan energi di dalam tubuh. Penelitian yang dilakukan oleh Al Rahmad (2019) menunjukkan bahwa anak dengan perilaku sedentari berisiko 4,6 kali menjadi gizi lebih dibandingkan anak yang aktif bergerak (7).

Densitas energi dan zat gizi belum banyak diteliti hubungannya dengan status gizi pada anak. Penelitian ini bertujuan untuk mengetahui hubungan densitas energi konsumsi, densitas asupan protein dan serat dengan status gizi pada anak usia 10-12 tahun.

Kecamatan Larangan, Kota Tangerang. Penelitian ini dilakukan pada bulan April 2020. Penelitian ini sudah memperoleh persetujuan etik dari Komite Etik Penelitian Kesehatan Universitas Muhammadiyah 
Prof.

DR.

HAMKA

No.03/20.03/0441/KEPK.

Populasi dalam penelitian ini adalah seluruh anak usia 10-12 di lingkungan RW 08 Larangan Selatan dengan teknik pengambilan sampel seluruh populasi adalah sampel penelitian, didapatkan sampel sebesar 46 subjek dengan syarat anak berusia 10-12 tahun, sehat dan siap untuk menjadi subjek penelitian.

Jenis pengumpulan data yang digunakan yaitu data primer dengan kuesioner food recall $2 \times 24$ jam dan pengukuran antropometri. Pengisian kuesioner food recall 2x24 jam dilakukan oleh enumerator dengan metode wawancara dan bantuan buku foto makanan. Food recall hari pertama dilakukan pada hari libur (weekend) sedangkan food recall kedua dilakukan untuk mengetahui asupan pada hari kerja (weekday).

Analisis data menggunakan analisis univariat untuk mendeskripsikan karakter masing-masing variabel yang diteliti dan analisis bivariat untuk mengetahui hubungan dari masing-masing variabel dengan status gizi anak menggunakan program Microsoft Excel 2013 dan program SPSS 20.0 for Windows. Uji bivariat yang digunakan adalah uji korelasi Spearman. Derajat kemaknaan yang dipakai adalah alpha 5\%, dengan p-value < 0,05 .

\section{HASIL}

Sebagian besar $(69,6 \%)$ subjek memiliki status gizi normal, diikuti oleh status gizi lebih atau gemuk $(26,1 \%)$. Densitas asupan energi dan asupan protein subjek yang lebih dominan pada kategori cukup yaitu sebesar $(65,2 \%)$ dan (87\%). Densitas asupan serat Sebagian besar anak $(97,8 \%)$ termasuk dalam kategori rendah (Tabel 1).

Subjek dengan status gizi gemuk lebih banyak ditemukan pada subjek dengan densitas asupan energi tinggi $(85,5 \%)$ dibandingkan pada subjek dengan densitas asupan energi rendah hingga cukup $(16,7 \%)$. Hal ini menunjukkan bahwa semakin tinggi densitas asupan energi maka semakin tinggi pula z-skor IMT/U (Tabel 2). 


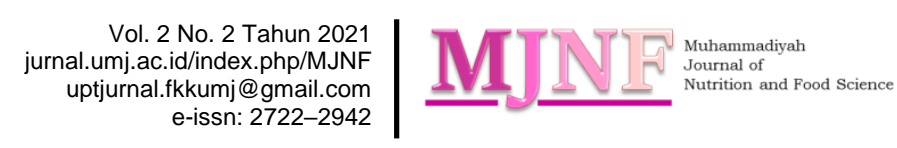

Tabel 1. Distribusi status gizi, densitas asupan energi, protein, dan serat pada anak 10-12 tahun

\begin{tabular}{lcc}
\hline \multicolumn{1}{c}{ Variabel } & n & \% \\
\hline Status Gizi & 2 & 4,3 \\
$\quad$ Kurus < -2 SD & 32 & 69,6 \\
$\quad$ Normal -2 s/d 1 SD & 12 & 26,1 \\
$\quad$ Gemuk > 1 SD & & \\
Densitas Asupan Energi & 8 & 17,4 \\
$\quad$ Rendah & & \\
$\quad$ (Laki-laki: < 1,7 kkal/g; Perempuan: < 1,6 & & \\
$\quad$ kkal/g) & 30 & 65,2 \\
$\quad$ Cukup & & \\
$\quad$ Laki-laki: $1,7-2,1$ kkal/g; Perempuan: $1,6-2,0$ & & \\
$\quad$ kkal/g) & 8 & 17,4 \\
$\quad$ Tinggi & & \\
$\quad$ (Laki-laki: > 2,1 kkal/g; Perempuan: > 2,0 & & \\
$\quad$ kkal/g) & & \\
Densitas Asupan Protein & 40 & 87 \\
$\quad$ Cukup $\geq 20$ g/1000 kkal & 6 & 13 \\
$\quad$ Rendah < 20 g/1000 kkal & & \\
Densitas Asupan Serat & 1 & 2,2 \\
$\quad$ Cukup $\geq 16$ g/1000 kkal & 45 & 97,8 \\
$\quad$ Rendah < 16 g/1000 kkal & & \\
\end{tabular}

Tabel 2. Hubungan antara densitas energi, densitas protein, densitas serat dengan status gizi (IMT/U)

\begin{tabular}{|c|c|c|c|c|c|c|c|c|c|}
\hline \multirow{3}{*}{ Variabel } & \multicolumn{6}{|c|}{ Status Gizi } & \multirow{3}{*}{ Total } & \multirow{3}{*}{$\begin{array}{c}p- \\
\text { value }\end{array}$} & \multirow{3}{*}{$r$} \\
\hline & \multicolumn{2}{|c|}{ Kurus } & \multicolumn{2}{|c|}{ Normal } & \multicolumn{2}{|c|}{ Gemuk } & & & \\
\hline & $\mathbf{n}$ & $\%$ & $\mathbf{n}$ & $\%$ & $\mathbf{n}$ & $\%$ & & & \\
\hline Densitas Asupan Energi & & & & & & & & & \\
\hline $\begin{array}{l}\text { Rendah } \\
\text { (Laki-laki: < 1,7 kkal/g; Perempuan: < 1,6 } \\
\text { kkal/g) }\end{array}$ & 2 & 25 & 6 & 76 & 0 & 0 & 8 & & \\
\hline Cukup & 0 & 0 & 25 & 83,3 & 5 & 16,7 & 30 & & \\
\hline $\begin{array}{l}\text { (Laki-laki: 1,7-2,1 kkal/g; Perempuan: 1,6- } \\
2,0 \mathrm{kkal} / \mathrm{g} \text { ) }\end{array}$ & & & & & & & & 0,000 & 0,621 \\
\hline $\begin{array}{l}\text { Tinggi } \\
\text { (Laki-laki: > 2,1 kkal/g; Perempuan: > 2,0 } \\
\text { kkal/g) }\end{array}$ & 0 & 0 & 1 & 12,5 & 7 & 85,5 & 8 & & \\
\hline Densitas Asupan Protein & & & & & & & & & \\
\hline Cukup $\geq 20 \mathrm{~g} / 1000 \mathrm{kkal}$ & 2 & 5 & 31 & 77,5 & 7 & 17,5 & 40 & $\cap 001$ & $=470$ \\
\hline Rendah < 20 g/1000 kkal & 0 & 0 & 1 & 16,7 & 5 & 83,3 & 6 & 0,001 & $-0,4 / 0$ \\
\hline Densitas Asupan Serat & & & & & & & & & \\
\hline Cukup $\geq 16 \mathrm{~g} / 1000 \mathrm{kkal}$ & 0 & 0 & 1 & 100 & 0 & 0 & 1 & 0 167 & ת 0207 \\
\hline Rendah $<16 \mathrm{~g} / 1000 \mathrm{kkal}$ & 2 & 4,4 & 31 & 68,9 & 12 & 26,7 & 45 & 0,101 & $-0,20 /$ \\
\hline
\end{tabular}

*Spearman's correlation

\section{PEMBAHASAN}

Status gizi anak dipengaruhi oleh banyak faktor baik faktor langsung maupun tidak langsung. Faktor langsung yang dapat memengaruhi status gizi anak adalah asupan makan dan aktivitas fisik. Status gizi dalam penelitian ini dinilai berdasarkan Indeks Massa Tubuh menurut Usia (IMT/U). Status gizi dikategorikan menjadi tiga yaitu "kurus", "normal", dan "gemuk". 
Proporsi status gizi lebih di lingkungan RW 08 Larangan Selatan ini cukup tinggi jika dibandingkan dengan penelitian yang dilakukan di kecamatan Rajeg, Tangerang yang menunjukkan angka sebesar 7,3\% dan Ningsih et al. (2016) di Kepulauan Meranti, yang hanya menunjukkan angka sebesar $9,5 \%(8,9)$.

Berdasarkan penelitian ini dapat menggambarkan bahwa ada kecenderungan anak usia 10-12 tahun di RW 08 Larangan Selatan, Tangerang untuk mengonsumsi makanan padat energi atau berdensitas energi tinggi namun rendah densitas zat gizi baik protein, zat gizi mikro dan juga serat. Hal tersebut menunjukkan kualitas konsumsi pangan anak yang masih rendah.

Densitas asupan energi dihitung menggunakan total kalori dari makanan dan minuman yang dikonsumsi dalam sehari dibagi dengan berat pangan sehari (10). Pada penelitian ini, standar total energi yang digunakan adalah per 1.000 kkal. Berdasarkan hasil penelitian didapatkan densitas asupan energi berhubungan secara signifikan dengan status gizi anak dengan korelasi positif yang kuat antara keduanya $(\mathrm{p}<0,05)$. Hal ini sesuai dengan penelitian yang dilakukan oleh Vernarelli et al., (2011) yang menunjukkan bahwa terdapat hubungan antara densitas asupan energi yang tinggi dengan berat badan anak (11). Pada penelitian Ekaningrum et al. juga ditemukan bahwa densitas asupan energi tidak berhubungan secara signifikan dengan status gizi namun memiliki korelasi positif yang cukup kuat antara keduanya yang berarti semakin tinggi densitas energi yang dikonsumsi seorang anak maka semakin besar pula z-skor IMT/U (12).

Jenis makanan yang sering dikonsumsi oleh subjek pada penelitian ini ialah berupa aneka biskuit, wafer, dan ice cream, dimana makanan-makanan tersebut adalah makanan padat energi sehingga sangat mungkin akan memengaruhi berat badan yang nantinya berdampak pada peningkatan status gizi individu.

Sebagian besar subjek memiliki densitas asupan protein yang cukup. Namun demikian, terdapat kecenderungan anak dengan status gizi gemuk untuk mengonsumsi makanan berdensitas asupan protein yang rendah. Hasil uji statistik menunjukkan bahwa ada hubungan yang signifikan antara densitas asupan zat gizi protein dengan status gizi dan berpola negatif dengan korelasi sedang $(\mathrm{p}<0,05)$.

Jenis bahan makanan sumber protein yang sering dikonsumsi oleh subjek berupa protein hewani seperti telur dan ayam yang diolah dengan metode penggorengan serta jarang mengonsumsi sumber protein nabati. Selain itu, porsi sumber bahan makanan karbohidrat seperti nasi dalam satu kali waktu makan yang dikonsumsi oleh subjek cukup besar yakni sekitar 200-300 gram per kali waktu makan. Hal ini menyebabkan proporsi kalori dari zat gizi makro terhadap total energi dalam sehari yaitu karbohidrat, lemak, dan protein menjadi tidak seimbang sesuai rekomendasi.

Proporsi protein pada subjek dengan status gizi gemuk pada penelitian ini cenderung hanya berkisar antara 8-10\% dari total energi. Jika dibandingkan dengan standar rekomendasi oleh World Health Organization (WHO) dan International Organization for Migration (IOM) sebesar 15\% maka dapat dikatakan di bawah standar (13). Oleh karena itu, mengakibatkan rendahnya asupan protein harian yang akan berdampak pada rendahnya densitas asupan protein per 1000 kkal pada anak gemuk. Hal ini sesuai dengan penelitian yang dilakukan oleh Fauzi yang menunjukkan bahwa terdapat hubungan yang signifikan antara densitas 
asupan protein dengan status gizi dimana anak dengan status gizi gemuk dan obesitas lebih banyak ditemukan pada subjek dengan densitas asupan protein yang rendah dibandingkan pada anak dengan densitas asupan protein cukup hingga tinggi (14). Penelitian senada juga menunjukkan bahwa ada hubungan yang signifikan antara asupan protein dengan status gizi anak dikarenakan sebagian besar subjek dominan mengonsumsi sumber protein hewani sehingga sumber makanan yang dikonsumsi kurang bervariasi (15).

Peranan serat dalam pola konsumsi makanan sangat penting. Serat makanan bermanfaat untuk mengontrol asupan energi, menurunkan berat badan dan risiko obesitas, serta mencegah terjadinya penyakit degeneratif (16-18). Akan tetapi, rendahnya asupan serat harian masyarakat Indonesia masih menjadi masalah hingga saat ini. Anak yang mengalami kelebihan berat badan, pada umumnya kurang asupan serat (19). Berdasarkan hasil penelitian ini, hanya terdapat satu subjek dengan status gizi normal yang memiliki densitas asupan serat cukup. Hal ini menggambarkan bahwa asupan serat harian anak masih rendah.

Hasil uji statistik menunjukkan bahwa tidak adanya hubungan yang signifikan antara asupan serat dengan status gizi, berpola negatif dengan kekuatan lemah ( $p>0,05)$. Tidak adanya hubungan antara densitas asupan serat dengan status gizi anak dikarenakan data yang homogen sehingga tidak mampu untuk menggambarkan variasi atau perbedaan antar subjek. Meskipun demikian, berdasarkan hasil penelitian menunjukkan arah uji korelasi yang negatif artinya semakin rendah densitas asupan serat dan asupan serat anak maka semakin besar nilai z-score IMT/U. Hasil tersebut sejalan dengan penelitian yang dilakukan oleh
Agustina et al. yang menunjukkan bahwa tidak ada hubungan yang signifikan antara asupan serat dengan status gizi anak usia 612 tahun. Hal ini dikarenakan rata-rata asupan serat pada anak usia 6-12 tahun di dalam penelitian tersebut yang masih tergolong rendah dan homogen sehingga tidak mampu untuk menggambarkan variasi (20). Fakta bahwa ini adalah studi cross-sectional berbasis satu lokasi menunjukkan bahwa penelitian ini mungkin kurang dapat digeneralisasi ke seluruh populasi.

\section{SIMPULAN}

Hasil penelitian menunjukkan terdapat hubungan yang signifikan antara densitas asupan energi dan densitas asupan protein dengan status gizi IMT/U pada anak usia 10-12 tahun di wilayah RW 08 Larangan Selatan, Tangerang. Terdapat hubungan yang positif antara densitas asupan energi dengan status gizi anak. Sebaliknya, terdapat hubungan yang negatif antara densitas asupan protein dan serat dengan status gizi anak. Penggiatan edukasi gizi pada masyarakat khususnya terkait peningkatkan konsumsi sayur dan buah serta makanan terutama jajanan yang tinggi densitas energi namun rendah densitas zat gizi menjadi prioritas sehingga asupan makan anak-anak Indonesia bisa lebih berkualitas.

\section{UCAPAN TERIMA KASIH}

Penulis menyampaikan terima kasih kepada responden dan tokoh masyarakat wilayah Larangan Selatan, Tangerang yang terlibat dalam penelitian ini.

\section{KONFLIK KEPENTINGAN}

Tidak ada konflik kepentingan pada penelitian ini. 


\section{REFERENSI}

1. Kementrian Kesehatan Republik Indonesia. Rencana Strategis Kementerian Kesehatan Tahun 2015-2019. 2015.

2. World Health Organization. Obesity and overweight [Internet]. 2016. Available from: www.who.int/newsroom/fact-sheets/detail/obesity-andoverweight

3. Kementerian Kesehatan Republik Indonesia. Laporan Riskesdas 2018. Jakarta; 2018.

4. Kelsey MM, Zaepfel A, Bjornstad P, Nadeau KJ. Age-related consequences of childhood obesity. Gerontology. 2014;60(3):222-8.

5. Sulfa UF. Makanan Padat Energi dan Rendah Mikronutrien sebagai Faktor Risiko Kejadian Obesitas pada Remaja Stunting Usia 13-15 Tahun di Kota Semarang. Universitas Diponegoro; 2016.

6. Duncan S, Duncan EK, Fernandes RA, Buonani C, Bastos KD-N, Segatto AFM, et al. Modifiable risk factors for overweight and obesity in children and adolescents from São Paulo, Brazil. BMC Public Health [Internet]. 2011;11(1):585. Available from: https://doi.org/10.1186/1471-245811-585

7. Al Rahmad AH. Keterkaitan Asupan Makanan dan Sedentari dengan Kejadian Obesitas Pada Anak Sekolah Da sar di Kota Banda Aceh. Bul Penelit Kesehat [Internet]. 2019 Jun 19;47(1):67-76. Available from: https://ejournal2.litbang.kemkes.go. id/index.php/bpk/article/view/579

8. Anzarkusuma IS, Mulyani EY, Jus'at I, Angkasa D. Status Gizi Berdasarkan Pola Makan Anak
Sekolah Dasar Di Kecamatan Rajeg Tangerang (Nutritional Status Based on Primary School Student'S Dietary Intake in Rajeg District Tangerang City). IJHN (Indonesian J Hum Nutr [Internet]. 2014;1(2):13548. Available from: https://ijhn.ub.ac.id/index.php/ijhn/a rticle/view/109/115

9. Ningsih YA, Suyanto, Restuastuti T. Gambaran Status Gizi Pada Siswa. Jom Fk. 2016;3(2):1-12.

10. Annisa PA. Densitas Energi Konsumsi, Status Gizi, Dan Daya Ingat Sesaat Anak Usia Sekolah Dasar. J Gizi dan Pangan. 2015;9(3):187-94.

11. Vernarelli JA, Mitchell DC, Hartman TJ, Rolls BJ. Dietary Energy Density Is Associated with Body Weight Status and Vegetable Intake in U.S. Children. J Nutr [Internet]. 2011 Dec 1;141(12):2204-10. Available from: https://academic.oup.com/jn/article/ 141/12/2204/4689028

12. Ekaningrum AY, Sukandar D, Martianto D. Keterkaitan Densitas Gizi , Harga Pangan dan Status Gizi. J Gizi dan Pangan [Internet]. 2017 Jul 7;12(2):139-46. Available from: http://journal.ipb.ac.id/index.php/jgi zipangan/article/view/18717/13216

13. Hardinsyah H, Riyadi H, Napitupulu D. Kecukupan energi, protein, lemak dan karbohidrat. Fakultas Kedokteran Universitas Indonesia; 2013.

14. Fauzi A. Analisis Densitas Asupan Zat Gizi dan Hubungannya Dengan Status Gizi Siswa Sekolah Dasar di Kota Bogor. Institus Pertanian Bogor; 2014.

15. Parinduri MS, Safitri DE. Asupan 
Karbohidrat Dan Protein

Berhubungan Dengan Status Gizi

Anak Sekolah Di Syafana Islamic

School Primary, Tangerang Selatan Tahun 2017. ARGIPA (Arsip Gizi dan Pangan). 2018;3(1):48-58.

16. Makaryani RY. Hubungan Konsumsi Serat Dengan Kejadian Overweight Pada Remaja Putri SMA Batik 1 Surakarta. Universitas Muhammadiyah Jakarta;

17. Salsabilah G, Nuzrina R. Perbedaan Asupan Zat Gizi Makro dan Serat Berdasarkan Status Gizi Anak Usia 7-12 Tahun di Kepulauan Nusa Tenggara (NTT dan NTB)(Analisis Data. 2018;7(April). Available from: https://digilib.esaunggul.ac.id/public /UEU-Journal-20172-11_1325.pdf

18. Rachmawati RK, Ardiaria M, Fitranti DY. Asupan Protein dan
Asam Lemak Omega 6 Berlebih Sebagai Faktor Risiko Kejadian Obesitas pada Anak Sekolah Dasar di Semarang. J Nutr Coll [Internet]. 2018 Nov 9;7(4):162. Available from:

https://ejournal3.undip.ac.id/index.p hp/jnc/article/view/22275

19. Lima Putri A. Gambaran Frekuensi Makan, Asupan Serat dan Kebiasaan Mengkonsumsi Camilan pada Anak Sekolah Dasar yang Overweight dan Obesitas di SDK Santa Maria Assumpta Kota Kupang. Poltekkes Kemenkes Kupang; 2019.

20. Agustina W, Mulyani EY, Kuswari M. Asupan Zat Gizi Makro Dan Serat Menurut Status Gizi Anak Usia 6-12 Tahun Di Pulau Sulawesi. J Gizi dan Pangan. 2015;10(1):63-70. 